\title{
Implications of the Greenhouse Effect on Crop Productivity
}

\author{
Sylvan H. Wittwer ${ }^{1}$ \\ Michigan State University, East Lansing, MI 48824
}

The big news story for 1988 was the so-called warming of the globe, known as the greenhouse effect. The protagonist was $\mathrm{CO}_{2}$. The theme was climate change. True, an enormous global and geophysical experiment is underway. It is projected that the consequences will affect the environment in which we all live: the climate, our water resources, the total biological productivity of the earth, and crop production. We are all participants in this event and will be exposed to its consequences. There are no exceptions. Humanity is currently exposing itself to rising levels of atmospheric $\mathrm{CO}_{2}$ and other so-called greenhouse gases, including methane, dinitrogen oxides, and chlorofluorocarbons. The result is the so-called "greenhouse effect" and a projected global warming (Revelle, 1982; Witwer, 1988).

It is now generally agreed that atmospheric $\mathrm{CO}_{2}$ concentrations have increased by at least $25 \%$ since early last century. During this span, fossil fuels have made a net contribution of $\approx 180 \mathrm{Gt}$ with deforestation and expanding agriculture adding another 100 to 200 Gt. Human activities have also led to release of other radiative gases listed above. Their combined and cumulative projected effects on the earth's climate are equivalent to an increase in atmospheric $\mathrm{CO}_{2}$ of $\approx 50 \mathrm{ppm}$ above the now observed concentration of $35.5 \mathrm{ppm}$. which is increasing at the rate of $2 \mathrm{ppm} / \mathrm{year}$. It is projected that the combined effects of increased concentrations of $\mathrm{CO}_{2}$ and other trace gases might lead to an equivalent of doubling the current level

${ }^{1}$ Director Emeritus. Michigan State Univ., Agricultural Experiment Station. of 355 ppm for $\mathrm{CO}_{2}$, as early as the 2030s (UNEP, 1985).

Extending the projection further as derived from climate models, the global mean equilibrium surface temperature would increase by 1.5 to $4.5 \mathrm{C}$ if the atmospheric $\mathrm{CO}_{2}$ concentration doubles. (Values outside this range, especially on the low end, should not be excluded.) With a projected global warming of 1.5 to $4.5 \mathrm{C}$, the sea level might rise 20 to $140 \mathrm{~cm}$ from thermal expansion of water. Major ice sheets, however, would not be expected to melt within the next century. It is further projected that doubling of atmospheric concentrations could profoundly affect global ecosystems, agricultural productivity, water resources, and sea ice. Further, it is now believed that during the first half of the next century, a rise in global mean temperature could occur that is greater than any time in our history (MacCracken and Luther, 1985a, 1985b; UNEP, 1985).

Interest was heightened in a so-called "greenhouse effect" by the drought and heat wave across the continental United States in May and June of 1988. By July, there were cover stories in news weeklies. II was the lead topic for broadcast news programs, and magazine write-ups appeared on what was presumed to be correlations between the heat wave and drought with a greenhouse effect. All this was coupled with the testimony of an over-zealous scientist that there was a $99 \%$ certainty the greenhouse effect was already here (Kerr, 1989). There was little, if any, scientific content in most of the stories that visually portrayed damaged crops, dried-up rivers, sweltering cities, and burning forests. All of this has rippled off into a plethora of conferences, symposia, and colloquia, of which this is one. Meanwhile, it has been authoritatively established that no greenhouse effect was involved with the drought and heat 
wave of 1988. It was the result of an out-of-position jet stream that directed storms into Canada rather than across the mid-United States (Schneider, 1989b; Trenberth et al., 1988).

This paper will address the implications of the greenhouse effect, or, more specifically, global climate changes induced by rising atmospheric levels-of $\mathrm{CO}_{2}$ and other greenhouse gases on crop productivity. Also considered will be the direct or biological effects of rising atmospheric levels of $\mathrm{CO}_{2}$ and possible climate-biological interactions on crop productivity.

In the biological sense, $\mathrm{CO}_{2}$ should not be considered an air pollutant, whereas much less is known of methane, dinitrogen oxides and the chlorofluorocarbons. In 1988, there was no "hotter" topic than the so-called "greenhouse effect," but in 1989 and again in 1990 the topic has cooled a bit. The central and eastern United States has been contrastingly cooler and wetter than 1988 .

\section{CLIMATE}

The most overriding variable projected to affect crop productivity arising from increasing levels of atmospheric $\mathrm{CO}_{2}$ is a warmer earth. Some warming appears inevitable. Based on real world observations thus far, however, it may be considerably less than the crude computer models indicate and almost everyone appears to believe (Smil, 1989). The projections are based upon predictive climate models. According to the majority that interpret them, there would be a global mean equilibrium surface temperature increase of 1.5 to $4.5 \mathrm{C}$ if the atmospheric $\mathrm{CO}_{2}$ doubles. Globally, the climate averages could warm by $3 \pm 1.5 \mathrm{C}$ by the end of the next century. The change would be greatest at the poles, with the least at the equator (Clark, 1982; Hansen et al., 1981; Manabe and Stouffer, 1979; Manabe and Wetherald, 1980; Manabe et al., 1981; Shepard, 1986; WMO, 1983).

Secondly, projected increases in temperature would induce widespread changes in precipitation patterns. For many crops and other plant species, a change in water availability would have a greater impact on both the magnitude and stability of crop production than temperature changes. Unlike global climatic changes, regional-scale climatic changes have not been modeled with confidence (Schneider, 1989a). This is also true of any future precipitation patterns.

A third global warming-induced variable for crop productivity that could be the most important for temperate zone agriculture would be both an increase in length and intensity of the growing season (Decker et al., 1985; Wittwer, 1980) or growing degree units (Rosenzweig, 1985). Seasonal and interannual variabilities in rainfall and snow cover, length of the growing season, and thermal variability in growing degree days (heat sums) are the climate concerns of farmers. Stability or dependability of production is as important as the magnitude of production itself.

The prospects of climate change from increasing atmospheric levels of $\mathrm{CO}_{2}$ should not unduly frighten horticulturists. Seasonal and interannual variabilities in climate have always made agriculture uncertain and a gamble. The purchase of a farm, acquisition of machinery, choice of a fertilizer formula and seed variety, and development of markets all depend upon next year's weather resembling last year's (Waggoner, 1983; Wittwer 1980).

Fortunately, the past century provides evidence that U.S. agriculture and its research establishment can cope with, and even improve, during climate change. Over the past 100 years, for example, the High Plains became the wheat belt during a moist period, then a Dust Bowl during a dry period. Agriculture, through migration and technology, was able to adapt. The course of yields for the major food crops in the United States, China, Japan, and the United Kingdom during the past century is a continuous upward trend, although there are significant yearly fluctuations, some of which were induced by war. During the last century one sees only upward trends attributable to new technology applied during both warm and cold and wet and dry periods. Interannual variations in climate for a particular location may equal or even exceed those projected for long-term trends associated with a presumed greenhouse effect.

Apprehension about a more prolonged climate trend in the future and a greater change can be balanced by the expectation that research, perhaps spurred by the opportunity of more $\mathrm{CO}_{2}$ for pho- tosynthesis and a reduced water requirement, can continue to increase crop yields. For the past 70 years, the variation in weather as reflected by the wheat fields of the United States, the USSR, China, India, Canada, and Australia has allowed nations with good weather to supply wheat to nations with bad weather.

While there is some assurance that U.S. agriculture can cope with the moderate climatic changes projected, such a change will add one more problem that agriculture must handle during the coming decades (Wittwer, 1980). Other problems facing agriculture include shortages of water, arable land, and fossil energy. Agricultural practices will continue to threaten the environment and must also deal directly with food safety and human health concerns. At the same time, there is the need to maintain agricultural production at high levels (Council for Agricultural Science and Technology, 1988). A projected climate change makes comprehensive agricultural research even more critical if we are to deal effectively with that change. A specific research initiative is needed to mount immediately a major effort to alleviate environmental stresses on crop production via conventional genetic improvement and genetic engineering, chemical treatments and management practices. This would be beneficial both as a buffer against short-term effects of variability, as a means of combating long-term climatic change, and to capitalize on existing genetic variation for enhancing production.

An extensive review of the $\mathrm{CO}_{2}$ climate issue by a joint committee of the World Meteorological Organization/International Council of Scientific Unions (WMO, 1983) reached a most perceptive conclusion that still holds. From a simple comparison of the overall temperature and $\mathrm{CO}_{2}$ increase for the last 100 years, one must conclude that the climate (temperature) sensitivity to $\mathrm{CO}_{2}$ is at the lower limit of mathematical climate model prediction. In other words, global temperatures in the past 100 years have risen less than half as much $(0.3$ to $0.7 \mathrm{C})$ as the same models that now predict a warming of 1.5 to $4.5 \mathrm{C}$ by the middle of the next century. This is based on the $25 \%$ rise in atmospheric $\mathrm{CO}_{2}$ that has already occurred. The global warming predicted by the models has not come to pass. More warming has occurred in the southern hemisphere, which is $90 \%$ covered by water, than the north, even though water is supposed to take longer to warm than land. The models also claim the far north latitude should warm the most, yet Alaska had record cold in the winter of 1988. This strongly suggests a possible $1.5 \mathrm{C}$ or lower increase in global mean temperature with a doubling of the current atmospheric $\mathrm{CO}_{2}$ level and other gases. not the $4.5 \mathrm{C}$ or as much as $8 \mathrm{C}$ that is predicted by some over-zealous advocates. These observations confirm what has happened thus far in real world climatechange statistics. Also, it was concluded that a considerable fraction of the observed temperature variations during the past 100 to 150 years is related to causes other than $\mathrm{CO}_{2}$ (Lashof, 1989). The fact that model-projected temperature changes from a doubling of atmospheric $\mathrm{CO}_{2}$ have an estimated uncertainty factor of two lends further doubt as to the validity of models for an accurate assessment of what the future may hold. These facts and conclusions are vitally important in our consideration of future policies and actions related to biological productivity, crop production, water resources, human health and welfare in general. Moreover, as Hare (198.5) has emphasized. there are as yet no grounds for viewing a $\mathrm{CO}_{2}$ warming. if it occurs, as an unmitigated disaster. We can speculate as to gains as well as losses, or winners and losers. Plants, in particular, may profit from $\mathrm{CO}_{2}$ enrichment. There may even be a net gain. This brings us to biological effects.

\section{DIRECT BIOLOGICAL EFFECTS: GREENHOUSE-GROWN PLANTS}

The beginnings of $\mathrm{CO}_{2}$ enrichment for improvement of plants in greenhouses took place over 100 years ago (Wittwer, 1986). As early as 1888 , the benefits of $\mathrm{CO}_{2}$ fertilization were recognized and reported for practical greenhouse culture in Germany, a few years later in England, and about 75 to 80 years ago in the United Stares. Favorable results were first reported for food crops and then for flowers and ornamentals.

Many reviews, conferences, assessments and compilations of literature have since been assembled, primarily of crops grown in 
controlled environments with the atmospheres variously enriched with $\mathrm{CO}_{2}$. Wittwer and Robb (1964) made a thorough assessment of past work and added data of their own, primarily for greenhousegrown tomatoes and lettuce. They related the results to commercial practices of growing crops to maturity under enriched $\mathrm{CO}_{2}$ atmospheric levels. The result was a substantial increase in yields of marketable products and an improvement in quality. Strain and Cure (1986) assembled extensive bibliographies of literature concerned with the direct effects of atmospheric $\mathrm{CO}_{2}$ enrichment on plants and ecosystems. Kimball (1983, 1985, 1986) reviewed 770 observations on agricultural yield enhancement of crops grown in greenhouses and subjected to elevated levels of atmospheric $\mathrm{CO}_{2}$. The overall yield increase was $32 \%$. The U.S. Dept. of Energy, with other concerned federal and state agencies, has sponsored extensive research programs and published numerous research reports on the direct effects of subambient and super-ambient $\mathrm{CO}_{2}$ levels on growth, photosynthesis, and water relations of a wide variety of commercially important crops in the United States (Abelson, 1989; Allen et al., 1987; Bazzaz et al., 1986; Callalway and Currie, 1985; Carlson and Bazzaz, 1980; Clark, 1982; Cooper, 1982; Cure, 1986; Kimball and Mitchell, 1979; Strain and Bazzaz, 1983; Strain and Cure. 1986). The primary purpose of a 1982 international conference (Lemon, 1983) was to identify researchable issues relating to first-order or direct biological effects of rising atmospheric $\mathrm{CO}_{2}$ on plant productivity. An inseparable linkage among biological effects, such as photosynthetic efficiency (Downton et al., 1981; Pearcy and Bjorkman, 1983; Tolbert and Zelitch, 1983), water use efficiency (Strain and Bazzaz, 1983), and biological N fixation (Lamborg et al., 1983) with the climatic resources of sunlight, temperature, and moisture, was recognized (Baker and Enoch, 1983; Strain and Bazzaz, 1983). The subject focus of this paper is, in part, a followup of that conference. More thorough documentation of the direct effects of $\mathrm{CO}_{2}$ on plant productivity appeared in 1985-86 with a series of reports by the U.S. Dept. of Energy (Baker and Enoch, 1983; Strain and Cure, 1986; White, 1985) and my most recent review (Wittwer, 1985). These were followed by two volumes assembled and edited by Enoch and Kimball on Carbon Dioxide Enrichment of Greenhouse Crops covering the status and $\mathrm{CO}_{2}$ sources (Enoch and Kimball, 1986) and physiology, yield, and economics (Enoch and Kimball, 1986).

There is, and has been for 25 years, an active working group on $\mathrm{CO}_{2}$ nutrition as a unit of the Commission on Protected Cultivation of the International Society for Horticultural Science. This working group sponsors symposia on the direct or positive effects of elevated levels of $\mathrm{CO}_{2}$ for increasing the productivity and quality of greenhouse-grown crops. They also publish an annual newsletter with an update on latest developments with respect to $\mathrm{CO}_{2}$ fertilization for tomatoes, cucumbers, peppers, lettuce, pot plants, and flowers. One of their latest reports (Mortensen, 1986) is on summer $\mathrm{CO}_{2}$, enrichment for tomatoes resulting in $12 \%$ to $13 \%$ increases in yields when levels of atmospheric $\mathrm{CO}_{2}$ are maintained at $335 \mathrm{ppm}$.

The two most significant direct effects of elevated levels of atmospheric $\mathrm{CO}$, are on photosynthesis and water use efficiency.

\section{PHOTOSYNTHETIC EFFICIENCY}

There is little doubt that current atmospheric levels of $\mathrm{CO}_{2}$ are suboptimal for photosynthesis when other factors affecting plant growth (light, water, temperature, nutrients) are optimal (Downton et al., 1981; Osmond et al., 1980). Net photosynthesis is the sum of gross photosynthesis minus photorespiration. Photorespiration may be of such magnitude that up to $50 \%$ of the $\mathrm{CO}_{2}$ newly fixed into carbohydrate may be oxidized back to $\mathrm{CO}_{2}$. With the currently rising levels of atmospheric $\mathrm{CO}_{2}$ and those yet projected, photorespiration rates may be expected to decrease (Tolbert and Zelitch, 1983). Increases in biomass are generally observed with atmospheric $\mathrm{CO}_{2}$ enrichment. This may not always come from an increase in net photosynthesis. $\mathrm{A} \mathrm{CO}_{2}$-induced greater water use efficiency with $\mathrm{C}_{4}$ plants, such as corn, Is largely responsible for the resultant growth stimulation (Rogers et al., 1980, 1981, 1984).

The most verifiable direct effect of high levels of $\mathrm{CO}_{2}$ on plants is an increase in leaf and canopy photosynthetic rates. The increase in photosynthesis with increasing atmospheric $\mathrm{CO}_{2}$ will continue up to $\approx 1000 \mathrm{ppm}$ (Kimball, 1983, 1986; Wittwer, 1985, 1986). the most obvious result is that plants grow faster and get bigger. There are differences among species. $\mathrm{C}_{3}$ species have a qualitatively greater photosynthetic response to elevated $\mathrm{CO}_{2}$ levels than the $\mathrm{C}_{4}$ species (Acock and Allen, 1986; Allen, 1979; Allen et al., 1984; Cure, 1986). There are usually increases in leaf areas, weight per unit area, leaf thickness, stem height, branching, and seed and fruit number and weight. Organ size may increase along with root : top ratios. The $\mathrm{C}: \mathrm{N}$ ratio increases. Most important of all, yields of the marketable product will most likely increase. Aside from overall increases in growth and earlier maturity, particularly noteworthy have been the direct effects of elevated levels of atmospheric $\mathrm{CO}_{2}$ on enhancement of tuber growth in potatoes (Arteca et al., 1979) and root growth in sweetpotatoes (Bhattachatya et al., 1985), biological $\mathrm{N}$ fixation in soybeans (Finn and Brun, 1982; Hardy and Havelka, 197.5; Lamborg et al., 1983; Phillips et al., 1976) and on root : top ratios. Generally, the harvest index, meaning those parts of the plant that command some economic importance, is increased. With a doubling of the current ambient $\mathrm{CO}_{2}$ concentration (350 $\mathrm{ppm}$ ) worldwide, agricultural yields may average an increase of $32 \%$ (Kimball, 1985, 1986). It is likely that some of the increases in global crop productivity witnessed during the past 50 to 100 years, may already be attributable to the rising level of atmospheric $\mathrm{CO}_{2}$. A tentative increase of $5 \%$ to $10 \%$ in productivity may be ascribed to this variable.

Important progress has been made during the past 10 years on the direct effects of $\mathrm{CO}_{2}$ enrichment on crops. The enhanced growth and yield from more $\mathrm{CO}_{2}$ for some plants is now widely recognized. Although numerous tests have been conducted on a few major crop plants (cotton, corn, wheat, soybeans, rice, potatoes, tomatoes, sweetpotatoes), usually under controlled or partly controlled environments, there is still a wide gap in knowledge about the responses in open fields of native species and ecosystems to $\mathrm{CO}_{2}$ enrichment.

\section{WATER USE EFFICIENCY AND WATER STRESS RESPONSES}

What agriculture needs more than anything else is water. One of the most critical unknowns in crop productivity is the pattern of drought frequency (Decker et al., 1985). Water is now and will become an even more-critical and limiting resource for agricultural productivity. Of the fresh water resources consumed annually in the United States, $80 \%$ to $85 \%$ go to crop irrigation. One-third of the world's food supply is now grown on $18 \%$ of the cropland that is irrigated.

An important aspect of increasing $\mathrm{CO}_{2}$ concentrations on plants is that the leaf stomates tend to partly close. This increases the resistance to comparative water loss, with decreases in leaf transpiration rates and an increase in water use efficiency.

Aside from the $\mathrm{CO}_{2}$ concentration in the atmosphere, wafer stress is the single most limiting factor for crop productivity. Evidence now accumulated that improved water use efficiency at elevated levels of atmospheric $\mathrm{CO}_{2}$ is associated with the greenhouse effect is an important finding for both agriculture and ecology. The implications are many. They include protection from or greater resilience of crops to drought and other water-related stresses, and a decrease in the quantity of water required for crops to mature and produce a harvestable product. There is the potential for greatly improved biological productivity. A modified water-use requirement could reduce water requirements for irrigation. An indirect effect would be an extension of the distribution and boundaries into semi-arid and desert areas for specific crops now constrained by water supplies. As a global antitransparent in biological productivity, $\mathrm{CO}_{2}$ could reduce overall evaporative water loss and increase water availability for use in agriculture and industry (CDIC Communications, 1985; Riebsame, 1988).

That high $\mathrm{CO}_{2}$ levels in the atmosphere alleviate water stress in plants has been confirmed (Carlson and Bazzaz, 1980.1982; Rogers et al., 1984; Rosenberg, 1981; Salomon and West, 1985; Sionit et al., 1980). Yields of water-stressed wheat at high $\mathrm{CO}_{2}$ levels were as large as or larger than those from well-watered wheat at normal 
$\mathrm{CO}_{2}$ (Gifford, 1979a, 1979b). Elevated levels of $\mathrm{CO}_{2}$ will increase water use efficiency in many plant species. Striking changes in water use efficiency and reduction in water use requirements have been summarized by Pearcy and Bjorkman (1983). Elevated $\mathrm{CO}_{2}$ effected stomatal closure and a reduction of transpiration rates. These effects progressed as levels of atmospheric $\mathrm{CO}_{2}$ rose. As stomatal conductance decreased in response to increased $\mathrm{CO}_{2}$, transpiration rates decreased proportionally, providing other variables were constant. The ratio of $\mathrm{CO}_{2}$ taken up in photosynthesis to the water lost in transpiration can be termed "photosynthetic water use efficiency." Water use efficiency also may be expressed in terms of the amount of biomass gain for the amount of water lost in a given period of time (Wittwer, 1985).

The direct effect of high atmospheric $\mathrm{CO}_{2}$ concentrations on photosynthesis of $\mathrm{C}_{3}$ plants is one of increasing photosynthetic water use efficiency. Stomatal conductance declines with increasing $\mathrm{CO}_{2}$ concentration in both $\mathrm{C}_{3}$ and $\mathrm{C}_{4}$ plants, but the $\mathrm{C}_{3}$ plants would likely benefit more from an increase in atmospheric $\mathrm{CO}_{2}$. Rogers et al. (1984) demonstrated that, with soybeans, high atmospheric $\mathrm{CO}_{2}$ not only promoted greater growth but prevented the onset of severe water stress under conditions of low water availability. Plants of a $\mathrm{C}_{3}$ photosynthetic pathway may benefit in dry matter production from high $\mathrm{CO}_{2}$ in three ways: enhancement of leaf expansion, increase in the photosynthetic rate per unit leaf area, and increase in water use efficiency.

There are still many unknowns concerning the consumptive use of water in crop production as it may be affected by rising levels of atmospheric $\mathrm{CO}_{2}$ and possible accompanying climate changes. Speculations as to landscape-scale consequences are premature in absence of actual field data for unconfined plants continually exposed to elevated levels of $\mathrm{CO}_{2}$. As suggested by Kimball (1985) and Acock and Allen (1986), plants are probably going to be larger and have a greater leaf area in the future high $\mathrm{CO}_{2}$ world. This will tend to increase transpiration. They will also likely have a larger, more vigorous root system to extract more water from the soil. A $\mathrm{CO}_{2}$-induced decrease in transpiration will make more thermal energy available for soil evaporation. Consequently, the amount of consumptive water use (and required irrigation) that will be reduced by twice the current level of atmospheric $\mathrm{CO}_{2}$ very likely will be less than the potential 33\% reduction in leaf transportation. Reductions up to $10 \%$ might reasonably be expected. This could still be very significant in world agriculture. Plants whose relative stomatal closure in high $\mathrm{CO}_{2}$ is more than their leaf area increase are more likely to have a reduction in water use. If warmer temperatures occur, however, as is projected, along with the rise in global $\mathrm{CO}_{2}$ concentration, we may also see a partially compensating rise in transpiration (Martin et al., 1989).

\section{CROP PRODUCTIVITY: ADAPTABILITY TO PRESENT CLIMATIC RESOURCES}

Many crops are very adaptable to possible climate change. There is no place on earth too hot and humid to grow rice, cassava, sweetpotatoes, or plantains. They are all major staple food crops and rank as number one in many agriculturally developing countries. A global warming would extend the currently set climatic boundaries both north and south. Maize, the third major food crop, and number one in the United States, is grown in more diverse areas of the earth than any other crop. This includes the lowland humid or high elevation tropics and throughout the temperate zone. Commercial production has moved $800 \mathrm{~km}$ further north in the United Slates during the past 50 years and continues as a major southern crop. Soybeans and field beans, two of the world's leading legumes, can be grown successfully from the equator to the 50th latitude north or south. Winter wheat, which is generally much more productive than spring wheat, has moved $360 \mathrm{~km}$ further north in the USSR since 1930. The U.S. winter wheat zone could be moved $360 \mathrm{~km}$ northward using a new genetic level of winter hardiness (Wittwer, 1980). The projected global warming, especially during the winter months and at high latitudes, could greatly speed up the process, or may not make necessary the introduction of new genetic material. There are some places now too hot and humid for wheat to grow, but genetic material is now on hand at CIMMYT and elsewhere to make that possible soon. It is projected that a doubling of $\mathrm{CO}_{2}$ and the projected climate change would increase production in North America (Rosenzweig, 1985; Wilks, 1988) and likely hold for northern Europe, the USSR, and China, as well as South America. Other crops of more horticultural interest, such as potatoes, sweet corn, green beans, tomatoes, celery, cabbage, onions, head lettuce, broccoli, and strawberries are currently grown, or could be at some season of the year, in every state in the United States. Both the most southern and northern boundaries for successful cotton, maize, rice, sugar beets, and watermelons are being extended by the use of plastic film covers. This is occurring most successfully and extensively in Japan, Korea, and China. In any event, if there will be a global warming within the magnitudes projected, this might be preferable to another ice age, also predicted about a decade ago, especially with most of the world's food production now concentrated between $30^{\circ}$ and $50^{\circ}$ north and south latitudes (Smil, 1989).

The future adaptability of agricultural crop production can also be indexed by already observed rates of change. Hybrid maize production in Iowa increased from $5 \%$ to $95 \%$ of the total area devoted to maize between 1935 and 1940 . The area of high-yielding wheat cultivars in India went from $0 \%$ to $82 \%$ of the total between 1967 and 1977 . Over $80 \%$ of the cultivated land in the Philippines is now planted to high-yielding rice cultivars. Rice production in Indonesia doubled from 1980 to 1985 . Within a decade, hybrid maize became a major crop in northern Europe, soybeans in Brazil, sunflowers in the Red River Valley of the northern United States, oil palm in Malaysia, and canola (rape) in Canada. Sunflowers, potatoes, sweet corn, onions, and carrots can be grown from Texas to Minnesota, even Alaska, and in practically every agriculturally developing country either in the northern or southern hemispheres. Important trees, such as aspen, red maple, Douglas-fir, and ponderosa pine are found from Canada to Mexico. Making the Minnesota climate that of Texas, which would be an extreme rendition of even the most exaggerated predictive climate modeling but already artistically portrayed in some cartoons, would not eliminate many crops. A warming as projected might expand successful commercial production of mangos, papayas, litchee, passion fruit, bananas, and pineapple in what are now our most southern continental states. Tropical and subtropical fruits could become more important, both imported and those grown domestically.

Although the severity is unknown, a warming trend of some magnitude would occur coincident with increased variability of precipitation. These changes could exceed past interannual variations, especially in temperate zones. The unknowns also outweigh the knowns. One option would be a prudent course of preparing for the worst. This would mean a massive effort in energy conservation, designing energy sources other than fossil fuels, reforestation, tree plantings, and the promulgation of conservation tillage.

\section{REGIONAL PROJECTIONS: CLIMATIC PATTERNS AND CROP RESPONSES}

There is no controversy that atmospheric $\mathrm{CO}_{2}$ has increased by $\approx 25 \%$ since 1850 because of fossil fuel combustion and land use (mostly deforestation). Levels of other so-called trace "greenhouse gases" such as methane, dinitrogen oxides, and chlorofluorocarbons have also increased by even larger factors. It is claimed by some that the combined effects of trace greenhouse gases will equal that of $\mathrm{CO}_{2}$. There is, however, great controversy as to whether global warming's first signal has already been detected (Kerr, 1989). There is a similar controversy, already referred to, as to the magnitude of such a global warming, if it occurs, during the next century. Estimates and projections range from a negative change to 1.5 to $6 \mathrm{C}$ or even higher. Forecasts of regional climatic change with distribution of variables. such as soil moisture or precipitation patterns, have even greater uncertainties. It is within such a backdrop of uncertainties that we review some of the reports that relate to implications of the greenhouse effect on crop productivity. Some of the possible impacts of climate change on agriculture are summarized in two recent volumes initiated by the International Institute for Applied Systems Analysis. The first is entitled, Assessments in 
Cool Temperate and Cold Region (Parry et al., 1988a); the second, Assessments in Semi-arid Regions (Parry et al., 1988b). Waggoner has summarized some of the effects on U.S. agriculture (Waggoner, 1983) and the impacts on western and other water reserves of a climate change (Waggoner, 1989). These were a follow-up of earlier papers (Wittwer, 1980, 1982) and were succeeded by an additional review (Waggoner, 1989) and other projections (Decker et al., 1985; National Academy Sciences, 1979). Finally, two comprehensive reports have appeared on $\mathrm{CO}_{2}$ climate change on U.S. agriculture (Adams et al., 1990; Ruttan, 1990).

These volumes, along with others, emphasize that there will be both negative and positive effects from a $\mathrm{CO}_{2}$-induced climate change. and that the direct effects of more $\mathrm{CO}_{2}$ in the air are, for the most part, beneficial to plants. More $\mathrm{CO}_{2}$ will cause leaves, as a result of the narrowing of stomata, to assimilate more carbon and lose less water. But if there is less rainfall in the American grain belt. as some very uncertain models suggest, the net effect or integration of both climatic and biological factors on yields is unknown (Martin et al., 1989). For overall effects on plants of the gradual changes in atmospheric $\mathrm{CO}_{2}$ and in climate foreseen for the year 2000 and beyond, some will be positive and some will be negative. The important message, however, is that the effects, direct, climatic, and those pertaining to water resources, will be manageable (Waggoner, 1989). Actions by farmers and by scientists can be done or taken bit by bit, and they extend present policies rather than require changes in the way we live (Abelson, 1989).

While regional-scale climate changes have not been modeled with any degree of confidence, there are many press reports and those circulated in slick magazines and Sunday supplements with speculative projections as to shifts and changes in crop productivity during the next 50 years. They include the following: Cereal crop production in Europe will not be affected as significantly as elsewhere. Cold, marginal regions, such as Canada, Alaska, Iceland, Scandinavia, New Zealand and the USSR should benefit considerably from higher crop yields associated with higher temperatures and longer growing seasons (Smit et al., 1989). The direct effects of $\mathrm{CO}_{2}$ enrichment should increase yields and tolerance to drought stress, although the effects may vary considerably according to plant species. A figure of $15 \%$ to $32 \%$ (Kimball, 1985) has been suggested, but such estimates are still very hypothetical. It is reasonable that a warmer climate will increase the length of the growing season, the growing degree units, and frost-free periods in both the northern and southern hemispheres. This could be significant for most horticultural crops whether flowers, fruits, vegetables, or ornamentals. The most pronounced effects would be near the poles, and specifically the north pole. The risk of freezing temperatures in Texas, Florida, and California and other western and southern states should be reduced under new climatic regimes induced by higher levels of atmospheric $\mathrm{CO}_{2}$. The production of winter wheat should be extended further north and south in the two hemispheres. If there is to be a warmer and drier climate in the U.S. grain belt, sorghum and millet could become more important crops in the west and south. It has been suggested that the U.S. corn belt might shift 175 $\mathrm{km}$ northeasterly for each 1C rise in temperature (Newman, 1980), and wheat production would shift eastward (Decker et al., 1985).

There are many more speculative projections as to the greenhouse effects on crop productivity. Farmers in Minnesota might see yields of maize and soybeans doubled, while in other more southern areas of the corn belt, production may not be possible. Michigan, New York, Pennsylvania, and southern Ontario could become even more important than they are now in fruit and vegetable production with more serious consideration of irrigation. Crop production in the southern states could shift to more citrus. Yields of major crops in the Great Plains could drop as irrigation water becomes limiting. A northern migration of agriculture would increase the use of irrigation and fertilizers on sandy soils, which may create or worsen ground water problems. Higher crop yields would require greater amounts of fertilizer and water. This was demonstrated over 25 years ago for vegetables grown in greenhouses and exposed to elevated atmospheric levels of $\mathrm{CO}_{2}$ (Wittwer and Robb, 1964). There may be significant effects on U.S. agricultural trade, especially with the Soviet Union. Global warming would help the Soviets boost wheat production by perhaps as much as $50 \%$ if a climate much like that of southern Canada were to occur. Crop production in China should be greatly enhanced with the northern migration of soybeans, winter wheat, rice, corn and cotton. Finally, assuming the climate models have a semblance of accuracy, there should be little change in the tropics. Thus, the agricultural crop productivity impacts on most developing countries in Central and South America, Africa, Southeast Asia and the islands of the Pacific should be minimal. Some regions and crops are climatically more vulnerable than others. North America is strategically critical to the stability of world food supplies. However, resources for crop production are usually most critical in agriculturally developing countries (Oram, 1985).

Projected $\mathrm{CO}_{2}$-induced climate changes have caused much speculation, and some research has been initiated on crop-pest relationships and changing strategies relating to crop protection. Weeds, insects, nematodes, and diseases inflict substantial losses on crops grown for food and in forests and on rangelands. A possible climate change will affect plant/crop pest relationships as well as have direct biological inputs. Plants will accumulate more carbohydrates and grow faster with elevated levels of $\mathrm{CO}_{2}$. Nutritional levels of carbohydrates and $\mathrm{N}$ will change, along with feeding habits of insects. This has been demonstrated by a few isolated studies (Fajer et al., 1989). A major factor in global warming could be greater survival, through overwintering and persistence of plant diseases and insects.

Pest control is, or should be, entering a new era with integrated management. Pests will change with weather and new entries (Waggoner, 1983). Of special interest and concern will be crop-weed interactions.

Of all crop pests, weeds are the most damaging. The current increases in atmospheric $\mathrm{CO}_{2}$ concentrations and projected warming will affect the growth and productivity of crops and associated weeds. Weeds compete directly with crops for water, sunlight, essential nutrients and atmospheric $\mathrm{CO}_{2}$. Estimated losses combined with the costs of weed control in the United States alone annually exceed $\$ 20$ billion. Of the 20 most important food crops, 16 have a $C_{3}$ photosynthetic pathway and four (maize, sorghum, millet, and sugarcane) have $\mathrm{C}_{4}$ pathways. However, of the world's 18 most noxious weeds, 14 are $\mathrm{C}_{4}$ plants. In contrast to the few $\mathrm{C}_{4}$ plants just noted that are important food crops, many of the major weeds are $\mathrm{C}_{3}$ plants. In fact, 19 of the 38 major weeds of maize in the United States are $\mathrm{C}_{3}$ plants. $\mathrm{C}_{3}$ and $\mathrm{C}_{4}$ plants respond differently to elevated levels of atmospheric $\mathrm{CO}_{2}$, the greater response being with the $\mathrm{C}_{3}$. It could be good fortune, with some major exceptions, that rising levels of atmospheric $\mathrm{CO}_{2}$ will generally favor crop production over weed growth. This could be of special benefit for horticultural crops, most all of which are $\mathrm{C}_{3}$ plants. For the moment, we do not know the effects of a projected warming and a higher $\mathrm{CO}_{2}$ on the productivity of $\mathrm{C}_{3}, \mathrm{C}_{4}$, and Crassulacean acid metabolism plants (most commonly represented by the pineapple) under real world conditions of crops and weeds, limited water, adverse temperatures, air pollution, restricted sunlight, or limited soil nutrients. (Kimball, 1985; Patterson and Flint, 1980, 1982; Waggoner, 1983; Wittwer, 1985).

\section{CONCLUSIONS}

We know for certain that the $\mathrm{CO}_{2}$ levels are rising globally. The increase has been an overall $25 \%$ with the advent of industrialization. In the last 65 to 70 years. there has been an approximate $22 \%$ increase, going from $\approx 290$ to the current level of $355 \mathrm{ppm}$. The rate of increase is now $2 \mathrm{ppm} / \mathrm{year}$. We are also reasonably sure that one of the prime causes of the rise is the release of $\mathrm{CO}_{2}$ from the combustion of fossil fuels. The progressively more rapid destruction of tropical and other forests is also a contributing factor, as is the excessive cultivation of land in crop production, which results in the irreversible oxidation of soil organic matter.

Currently, there is a widely prevailing perception that the threat from a greenhouse warming of the globe is growing progressively greater and it will become more costly and inconvenient to stabilize the future climate resources of the earth.

Counter to this concept is that most $\mathrm{CO}_{2}$ emission reduction measures would save money, protect the environment, conserve the 
natural resources of land, water, and energy, and improve the quality of life. We ought to proceed with the following actions immediately, independent of scare tactics of a greenhouse warming.

First, I refer to energy conservation and the development of energy resources independent of or alternative to the use of fossil fuels. We need to reinstate the energy conservation tactics of a decade ago-more efficient gasoline engines and improved mileage for automobiles, tractors, and trucks; the development of engines with greater fuel economy; a renewed research program for improved use of solar, wind, hydropower, and aromic energy; biological $\mathrm{N}$ fixation as an alternative to chemical fixation (which now requires large infusions of fossil energy); and finally, integrated pest management to reduce the use of chemicals. Such measures would not only greatly lessen the generation of atmospheric $\mathrm{CO}_{2}$, but would reduce crop production costs, result in environment improvements, and preserve nonrenewable resources for future generations.

Secondly, there should be a massive global program for reforestation and tree planting and a ban on further destruction of tropical forests in all agriculturally developing countries. It is estimated that tropical rain forests are disappearing at the rate of 8 million ha/ year. The exploitation of high-value species, such as mahogany, is proceeding al an accelerated rate in Central America. Reforestation would also tend to stabilize the levels of atmospheric $\mathrm{CO}_{2}$ and add to, rather than diminish, one of the great natural resources of the earth now vital for firewood, timber logs, soil stabilization, control of soil erosion and sedimentation and as a food source (agro-forestry). Again, reforestation with high-value species should proceed as a world-wide effort, independent of the frightening shadow of a global greenhouse effect. Currently, there is a striking positive correlation between the rate of deforestation and national foreign debts in most all agriculturally developing countries.

Thirdly, the presumed $\mathrm{CO}_{2}$-induced climate change could also be partially averted, or at least delayed, by soil conservation and tillage practices that would reduce the oxidation of organic matter, practically eliminate soil erosion, and make cropping and plant harvest an annual event in the tropics. I refer to conservation tillage and alley cropping.

Finally, there is an urgent need for increased research support to stabilize crop production through greater resistance to biological and environmental stresses, such as pests, weather aberrations, shortterm droughts, temperature extremes, aluminum toxicity, and related nutrient deficiencies of acid soils and soils of high salinity. Climatic stresses frequent almost all crops in all locations (Liverman, 1987). Making or developing plants (crops) more resistant to environmental stresses would have world-wide application and interest to meet the exigencies of the ever-present interannual climate variations. Such an initiative would be of benefit in crop production independent of a projected greenhouse warming. It would buffer short-term effects of variability and combat long-term climate change. It would be a step toward the catch phrase, low-input sustainable agriculture on a global scale.

At this moment no one really knows the earth's optima! concentration for $\mathrm{CO}_{2}$ and other so-called greenhouse gases for the most favorable total or accumulative effects on the environment, on crop productivity, on natural resources, on total biological productivity, or on human health or society. During my lifetime, I have witnessed a rise of atmospheric $\mathrm{CO}_{2}$ from $\approx 290$ to $>355 \mathrm{ppm}$. During this three-quarters of a century, there has been no verifiable climate change either for hot or cold; for dry or wet; nor any catastrophic climatic shifts with major impacts on crop productivity. The summer drought and heat wave of 1988 in the United States was not a so-called induced greenhouse effect but a shift in the jet stream. Meanwhile, it is difficult to accept the suppositions made repeatedly in the U.S. press, in quasi-scientific reports, and in testimonies before congressional committees and the conclusions and recommendations emanating from national and international conferences and symposia, that global temperatures may go up by $4.4 \mathrm{C}(8 \mathrm{~F})$ in an additional 70 years or less with major crop production dislocations. However, well-meaning scientists have learned that frightening the public gets results. We have been on a treadmill of ecological gloom ever since Earth Day of almost 20 years ago. We have been hit with one doomsday prediction after another. It was said that Lake Erie was "dead" or dying. They said DDT was killing all oceanlife. The population "bomb" was set to explode and worldwide famine was just around the corner. Now it's the greenhouse effect and destruction of the ozone layer.

If there are to be climatic changes as a result of the greenhouse effect, there will be impacts on crop productivity. But here, there will be both winners and losers. Higher $\mathrm{CO}_{2}$ levels, such as a doubling accompanied by warmer weather, would also have beneficial effects. There should also be milder winters, longer growing seasons, and more growing degree units. Above all, would be increased efficiency of photosynthesis and water use in plants and crops. The additive effects could well increase yields of crops by $>10 \%$ and could extend the boundaries of crop production, especially horticultural crops, now limited by insufficient moisture and cold temperatures.

Some warming appears inevitable, although it could, based on real world data, be much less than the still-crude computer models suggest and a handful of over-zealous prominent scientists and environmentalists promulgated in the hothouse atmosphere of a 1988 summer heat wave that quickly flowered luxuriantly into an accepted fact (Laing, 1989).

There are, however, some important facts to remember. The effects of climate changes on food and agriculture are readily identifiable global impacts of significant magnitude on future living standards. Virtually all agriculture everywhere is outdoors, although there are some horticultural exceptions. Agriculture depends on sun and rain or irrigation. It is sensitive to temperature. It is subject to both the beneficial and harmful activities of insects, diseases, microorganisms, and weeds, all of which in turn are affected by weather and climate.

Irrespective of agriculture's substantial dependence on weather and climate for the future, it is not yet possible, even with today's crops and today's technologies and today's distribution of agriculturally diverse activities over the earth, to assess the aggregate impact of projected climate change nor even to be certain of the arithmetic sign, whether it be plus or minus. There is a prevailing presumption among some that any climate change, independent of what the change is, has a disadvantageous expectation. There is also the rightful presumption that the direct effect of rising levels of atmospheric $\mathrm{CO}_{2}$ could have a globally positive effect on both photosynthetic and water use efficiency and thus rota! crop and biological productivity.

Agriculturists, and particularly horticulturists, have been noticeably silent concerning the "greenhouse effect." We ought to join the chorus for increased research on sources of energy alternatives to fossil fuels, encourage tree plantings, reforestation, and conservation tillage and above all support basic and applied research on greater resilience of crops to climatic and other environmental hazards and competing biological systems (National Academy of Sciences, 1976), including integrated pest management. Increased support of research in these areas was among the lop priorities recommended 12 years ago in the World Food and Nutrition Study (National Academy of Sciences, 1977). and at the International Conference on Crop Productivity-Research Imperatives at Boyne Highlands, Michigan, in 1975 and again in 1985. They remain, in most part, yet to be implemented. Support is also needed among horticulturists for research on the direct effects of rising levels of atmospheric $\mathrm{CO}_{2}$ and other greenhouse gases on crop productivity, research that has received minimal effort compared to that going into climate research. Climate research, among horticulturists, should not be neglected. In conclusion, the overall positive benefits and negative outputs-climatic, biological, social, economic, and political-of the rising level of atmospheric $\mathrm{CO}_{2}$ and other gases, still need resolution. However, my best estimate of the impact of a $\mathrm{CO}_{2}$-induced climate change on agriculture is that the change will not be catastrophic.

\section{Literature Cited}

Abelson. P.H. 1989. Climate and water (editorial). Science 243:461.

Acock, B. and L.H. Allen, Jr. 1986. Crop responses to elevated carbon dioxide concentrations, p. 53-97. In: B.R. Strain and J.D. Cure (eds.). 
Direct effects of increasing carbon dioxide on vegetation. Natl. Technical Information Serv. U.S. Dept. Commerce, Springfield, Va.

Adams, R.M.. C. Rosenzweig, R.M. Post, J.T. Ritchie, B.A. Carl, J.P. Glyer, R.B. Curry, J.M. Jones, K.J. Boote, and E.H. Allen, Jr. 1990. Global climate change and U.S. agriculture. Nature (London) 245:219 224

Allen, L.H. 1979. Potentials for carbon dioxide enrichment, p. 500-519. In: B.J. Barfield and J.F. Gerber (eds.). Modification of the aerial environment of crops. Amer. Soc. Agr. Eng. St. Joseph. Mich.

Allen, J.H., Jr., K.J. Boote, J. W. Jones, P.H. Jones. R.R. Valle, B. Acock, H.H. Rogers, and R.C. Dahlman. 1987. Response of vegetation to carbon dioxidc. U.S. Dept. Agr. and U.S. Dept. Energy, Washington, D.C.

Arteca, R.N., B.W. Poovaiah, and O.E. Smith. 1979. Changes in carbon dioxide fixation, ruberization and growth induced by $\mathrm{CO}_{2}$ applications to the root zone of potato plants. Science 205: 1279-1280.

Baker. D.N. and H.Z. Enoch (working group co-chairmen). 1983. Plant growth and development, p. 107-130. In: E.R. Lemon (ed.). $\mathrm{CO}_{2}$ and plants. Westview. Boulder, Colo.

Bazzaz, F.A., K. Garbutt, and W.E. Williams. 1986. Effect of increased atmospheric carbon dioxide concentration on plant communities, p. 155170. In: B.R. Strain and J.D. Cure (eds.). Direct effects of increasing carbon dioxide on vegetation. Natl. Technical lnformation Serv., U.S. Dept. Commerce, Springfield, Va.

Bhattacharya, N.C., P.K. Biswas, S. Bhattacharya, N. Sionit, and R.R. Strain, 1985. Growth and yield response of sweet potato (Ipomoea batatas) to atmospheric $\mathrm{CO}_{2}$ enrichment. Crop Sci. 25:975-981.

Callaway, J.M. and J.W. Currie. 1985. Water resource systems changes in climate and vegetation, p. 23-67. In: M.R. White (ed.). Characterization of information requirements for studies of $\mathrm{CO}_{2}$ effects: water resources, agriculture, fishcries, forests and human health. Natl. Technical Information Serv., U.S. Dept. Commerce, Springfield, Va.

Carlson, R.W. and F.X. Bazzaz. 1980. The effects of elevated $\mathrm{CO}_{2}$ concentrations on growth, photosynthesis, transpiration, and water use efficiency of plants. p. 609-623. In: J. Singh and A. Deepak (eds.) Environmental and climatic impact of coal utilization. Academic. New York.

Carlson, R.W. and F.A. Bazzaz. 1982. Photosynthetic and growth response to fumigation with $\mathrm{SO}_{2}$ at elevated $\mathrm{CO}_{2}$ for $\mathrm{C}_{3}$ and $\mathrm{C}_{4}$ plants. Oceologia 59:50-54

CDIC Communications. 1985. Carbon Dioxide Information Center, Oak Ridge National Laboratory, Oak Ridge, Tenn.

Clark, W.C. (ed.). 1982. Carbon dioxide review 1982. Oxford Univ. Press, New York.

Cooper. C.F. 1982. Food and fiber in a world of increasing carbon dioxide, p. 299-333. In: W.C. Clark (cd.). Carbon dioxide review: 1982. Oxford Univ. Press, New York.

Council for Agricultural Science and Technology. 1988. Long-term viability of U.S. agriculture. CAST Report no. 114. Ames, Iowa.

Cure, J.D. 1986. Carbon dioxide doubling responses: A crop survey, p. 99-116. In: B.R. Strain and J.D. Cure (eds.). Direct effects of increasing carbon dioxide on vegetation. Natl. Technical Information Serv., U.S. Dept. Commerce. Springfield, Va.

Decker, W.L., V. Jones, and R. Achutuni. 1985. The impact of $\mathrm{CO}_{2}$ induced climate change on U.S. Agriculture, p. 69-93. In: M.R. White (ed.) Characterizarion of information requirements for studies of $\mathrm{CO}_{2}$ effects: water resources, agriculture, fisheries, forests and human health Natl. Technical Information Serv., U.S. Dept. Commerce, Springfield, $\mathrm{Va}$

Downton, W.J.S., O. Bjorkman, and C. Pike. 1981. Consequences of increased atmospheric concentration of carbon dioxide for growth and photosynthesis of higher plants, p. 143-153. In: G.I. Pearman (ed.). Carbon dioxidc and climite: Australian research. Austral. Acad. Sci., Canberra.

Enoch. H.Z. and B.A. Kimball (eds.). 1986. Carbon dioxide. enrichment of greenhouse crops. vol. I. Status and $\mathrm{CO}_{2}$ sources. CRC Press, Boca Raton, Fla

Enoch, H.Z. and B.A. Kimball (eds.). 1986. Carbon dioxide enrichment of grecnhouse crops. vol. II. Physiology, yield, and economics. CRC Press, Boca Raton; Fla.

Fajer, E.D., M.D. Bowers. and F.A. Bazzaz. 1989. The effect of enriched carbon dioxide atmospheres on plant insect herbivore interactions. Science 243:1198-1200.

Finn, G.A. and W.A. Brun. 1982. Effect of atmospheric $\mathrm{CO}_{2}$ cnrichment on growth, nonstructural carbohydrate content, and root-nodule activity in soybean. Plant Physiol. 69:327-331.

Gifford. R.M. 1979a. Growth and yield of $\mathrm{CO}_{2}$ enriched wheat under waterlimited conditions. Austral. J. Plant Physiol. 6:367-378.

Gifford, R.M. 1979b. Carbon dioxide and plant growth under water and light stress. Implications for balancing the global budget. Search 10:316318 .

Hansen, J., D. Johnson, A. Lacis, S. Lcbedeff. P. Lee. D. Rind, and G.
Russell. 1981. Climatic impact of increasing atmospheric carbon dioxide. Science 213:957-966.

Hardy, R.W.F. and U.D. Havelka. 1975. Photosynthate as a major factor limiting nitrogen fixation by field grown legumes with emphasis on soybeans. Contributions to the scientific literature. Section IV, biology. E.I. DuPont de Nemours, Wilmington, Del. p. 58-76.

Hare, F.K. 1985. Climatic variability and change, p. 37-68. In: R.W. Kates, J.H. Ausubel, and M. Berberian (eds.). Climate impact assessment. SCOPE 27. Wiley, New York.

Kerr, R.A. 1989. Hansen vs. the world on rhe greenhouse threat. Science 244:1041-1043

Kimball, B.A. 1983. Carbon dioxide and agricultural yield. An assemblage and analysis of 770 prior observations. (WCL Report 14). U.S. Water Conserv. Lab. Phoenix, Ariz.

Kimball, B.A. 1985. Adaptation of vcgetative and management practices to a higher carbon dioxide world, p. 185-204. In: B.R. Strain and J.D. Cure (eds.). Direct effects of increasing carbon dioxide on vegetation. Nat. Technical Information Serv., U.S. Dept. Commerce, Springfield, $\mathrm{Va}$.

Kimball, B.A. 1986. Influence of elevated $\mathrm{CO}_{2}$ on crop yield. Carbon dioxide enrichment of greenhouse crops. vol. II. Physiology, yield and economics. CRC Press, Boca Raton, Fla. p. 105-115.

Kimball. B.A. and S.T. Mitchell. 1979. Tomato viclds from $\mathrm{CO}_{2}$ enrichment in unventilated and conventionally ventilated greenhouses. J. Amer. Soc. Hort. Sci. 104:515-520.

Laing, J.R. 1989. Climate of fear. The greenhouse effect may be mostly hot air. Barrons LX IX(9):6-7, 20, 22.

Lamborg, M.R., R.W.F. 'Hardy, and E.A. Paul (working group co-chairmen). 1983. Microbiological effects. p. 131-176. In: E.R. Lemon (ed.). $\mathrm{CO}_{2}$ and plants. Westview, Boulder; Colo.

Lashof, D.A. 1989. The dynamic greenhouse: feedback processes that may influence future concentrations of atmospheric trace gases and climate change. Climate Change 14:213-242.

Lemon, E.R. (ed.). 1983. $\mathrm{CO}_{2}$ and plants. The response of plants to rising levels of carbon dioxide. Westview, Boulder, Colo.

Liverman, D. 1987. Forecasting the input of climate on food supplies: model testing and model linkage. Climate Change 11:266-285.

MacCracken, M.C. and F.M. Luther (eds.). 1985a. Detecting the climatic effects of increasing carbon dioxide. Carbon Dioxide Res. Div., U.S. Dept. Energy, DOE/ER-0235, Washington, D.C.

MacCracken. M.C. and F.M. Luther (eds.). 1985b. The potential climatic cffects of increasing carbon dioxide. Carbon Dioxide Res. Div., U.S. Dept. Energy. DOE/ER-0237, Washington, D.C.

Manabe, S. and R. Stouffer. 1979. A $\mathrm{CO}_{2}$-climate sensitivity study with a mathematical model of global climate. Nature (London) 282:491-493.

Manabe, S. and R.T. Wetherald. 1980. On the distribution of climate change resulting from an increase in $\mathrm{CO}_{2}$ content of the atmosphere. J. Atmospheric Sci. 37:99-118.

Manabe, S., R.T. Wetherald. and R.J. Stouffer. 1981. Summer dryness due to an increase of atmospheric $\mathrm{CO}_{2}$ concentration. Climate Change $3: 347-386$

Martin, P., N.J. Rosenberg, and M.S. McKenney. 1989. Sensitivity of evapotranspiration in a wheat field, a forest, and a grassland to changes inclimate and direct effects of carbon dioxide. Climate Change 14:117151.

Mortensen, L.M. (chairman). 1986. Intl. Soc. Hort. Sci. Agr. Univ. of Norway, Aas. $\mathrm{CO}_{2}$ Nwsl.

National Academy of Sciences. 1976. Climate and food. A report of the Committee on Climare and Weather Fluctuations and Agricultural Production, Board on Agriculture and Renewable Resources, Commission on Natural Resources. Natl. Res. Council, Washington, D.C.

National Academy of Sciences. 1977. World food and nutrition study. The potential contributions of research. A report of the steering committee NRC study on world food and nutrition of the Commission on International Rclations. Natl. Res. Council. Washington, D.C.

National Academy of Sciences. 1979. Carbon dioxide and climate: a scientific assessment. Natl. Res. Council, Washington, D.C.

Newman, J.E. 1980. Climate change impacts on the growing season of the North American "corn bell." Biometeorology 7. (2): 128-142.

Oram, P.A. 1985. Sensitivity of agricultural production to climatic change. Climate Change 7:129-152.

Osmond. C.B.. O. Bjorkman, and D.J. Anderson. 1980. Physiological processes in plant ecology. Ecological Studies 36. Springer-Verlag, New York. p. 419-425.

Parry, M.L., T.R. Carter, and N.T. Konijn (eds.). 1988a. The impact of climatic variations on agriculture vol. 1: Assessments in cool temperate and cold regions. Kluwcr Academic, Boston.

Parry, M.L., T.R. Carter, and N.T. Konijn (eds.). 1988b. The impact of climatic variations on agriculture vol. 2: Assessments in semi-arid regions. Kluwer Academic, Boston. 
Patterson, D.T. and E.P. Flint. 1960. Potential effects of global atmospheric $\mathrm{CO}_{2}$ enrichment on the growth and competitiveness of $\mathrm{C}_{3}$ and $\mathrm{C}_{4}$ weed and crop plants. Weed Sci. 26:71-75.

Patterson, D.T. and E.P. Flint. 1962. Interacting effects of $\mathrm{CO}_{2}$ and nutrient concentration. Weed Sci. 30:389-394.

Pcarcy, R.W. and O. Bjorkman (working group co-chairmen). 1963. Physiological effects, p. 65-105. In: E.R. Lemon (ed.). $\mathrm{CO}_{2}$ and plants. Westview, Boulder, Colo.

Phillips, D.A., K.D. Newell, S.A. Hassall, and C.E. Filling. 1976. The effect of $\mathrm{CO}_{2}$ enrichment on root nodule development and symbiotic $\mathrm{N}_{2}$ reduction in Pisum sativum L. Amer. J. Bot. 63:356-362.

Revelle. R. 1962. Carbon dioxide and world climate. Scientific Amer. 247(2):35-43.

Ricbsame, W.E. 1986. Adjusting water resources management to climate change. Climate Change 13:69-97.

Roberts, L. 1966. Is there life after climate change? Science 242:10101012.

Rogers, H.H., G.E. Bingham, J.E. Cure, W.W. Heck, A.S. Heagle, D.W. Israel, J.M. Smith, K.A. Surano, and J.F. Thomas. 1960. Response of vegetation to carbon dioxide. Field studies of plant responses to elevated carbon dioxide. Rpt. no. 001. U.S. Dept. Energy and Dept. Agr. Washington, D.C.

Rogers, H.H., R.D. Beck, G.E. Bingham, J.D. Cure, J.M. Davis, W.W. Heck, J.D. Rawlings, J.J. Riordan, N. Sionit, J.M. Smith, and J.F. Thomas. 1981. response of vegetation to carbon dioxide. Field studies of plant responses to elevated carbon dioxide. Rpt. no. 005. Bot. Dept., North Carolina State Univ., Raleigh.

Rogers, H.H., J.F. Thomas, and G.E. Bingham. 1983. Response of agronomic and forest species to elevated atmospheric carbon dioxide. Science 220:428-429.

Rogers, H.H., N. Sionit, J.D. Cure, J.M. Smith and G.E. Bingham. 1964. Influence of elevated carbon dioxide on water relations in soybeans. Plant Physiol. 74:233-236.

Rosenberg, N.J. 1961. The increasing $\mathrm{CO}_{2}$ concentration in the atmosphere and its implication in agricultural productivity. 1. Effects in photosynthesis, transpiration and water use efficiency. Climate Change 3:265279.

Rosenzweig, C. 1965. Potential $\mathrm{CO}_{2}$ induced climate effects on North American wheat producing regions. Climate Change 7:367-369.

Rosenzweig, C. 1969. How it might be: Agriculture. Env. Protection Agency J. 15:9-10.

Ruttan, V.W. (ed.). 1990. Resource and environmental contraints on sustainable growth in agricultural production: Report on a dialog. Staff Paper P90-33. Dept. Agr. and Applied Econ., Univ. of Minnesota, St. Paul.

Salomon. A.M., and D.C. West. 1965. Potential responses of forests to $\mathrm{CO}_{2}$-induced climate change, p. 145-169. In: M.R. While (ed.). Characterization of information requirements for studies of $\mathrm{CO}_{2}$ effects: water resources, agriculture, fisheries, forests and human health. Natl. Technical Information Serv., U.S. Dept. Commerce, Springfield, Va.

Schneider, S.H. 1969a. The greenhouse effect: science and policy. Science 243:771-761.

Schneider, S.H. 1969b. The greenhouse effect and the U.S. summer of 1966. Cause and effect or a media event? (editorial). Climate Change 13:113-115.
Shepard, M. 1966. The greenhouse effect: earth's climate in transition. EPRI J. 11;5-15.

Sionit, N., H. Hcllmers. and B.R. Strain. 1980. Growth and yield of wheat under $\mathrm{CO}_{2}$ enrichment and water stress. Crop Sci. 20:667-690.

Smil, V. 1989. Our changing cnvironment. Current History 68:9-12, 4646.

Smir, B., M. Brklacich, R.B. Stewart, R. McBride, M. Brown, and D. Bond. 1969. Sensitivity of crop yields and land resource potential to climate changes in Ontario, Canada. Climate Change 14:153-174.

Smith, J.B. and D.A. Tirpak (eds.). 1988. The potential effects of global climate change on the United States. U.S. Env. Protection Agency. Washington, D.C.

Strain, B.R. and F.A. Bazzaz (working group co-chairmen). 1983. Terrestrial plant communities, p. 177-222. In: E. R. Lemon (eds.). $\mathrm{CO}_{2}$ and plants. Westview, Boulder, Colo.

Strain, B.R. and J.D. Cure. 1966. Direct effects of atmospheric $\mathrm{CO}_{2}$ enrichment on plants and ecosystems: a bibliography with abstracts. Nat. Technical Information Serv., U.S. Dept. Commerce, Springfield, Va.

Tolbert, N.E. and I. Zelitch (working group co-chairmen). 1983. Carbon metabolism, p. 21-64. in: E. R. Lemon (ed.). $\mathrm{CO}_{2}$ and plants. Westview, Boulder, Colo.

Trenberth, K.E., G.W. Branstator, and P.A. Arkin. 1966. Origins of the 1988 North American drought. Science 242:1640-1645.

UNEP. 1985. An assessment of the role of carbon dioxide and other greenhouse gasses in climate variations and associated impacts. United Nations Env. Program/World Mereorological Organization/Intl. Council of Scientific Unions. The Villach Conf. WMO, Geneva.

Waggoner, P.E. 1983. Agriculture and a climate changed by more carbon dioxide. Changing climate. Natl. Academy Press, Washington, D.C. p. 363-416.

Waggoner, P.E. (ed.). 1990. Climate and waler. Wiley, New York. (In press).

While, M.R. 1965. Characterization of information requirements for studies of $\mathrm{CO}_{2}$ effects: water resources, agriculture, fishcries, forests and human health. U.S. Dept. Energy. DOE/ER-0236, Washington, D.C.

Wilks, D.S. 1966. Estimating the consequences of $\mathrm{CO}_{2}$-induced climate change on North American grain agriculture using general circulation model information. Climate Change 13:19-42.

Wittwer, S.H. 1980. Carbon dioxide and climate change: an agricultura perspective. J. Soil and Water Conservation 35:116-120.

Wittwer, S.H. 1962. Agricultural adaptation to the rising level of atmos pheric carbon dioxide. p. 320-324. In: W.C. Clark (ed.). Carbon dioxide review: 1982. Oxford Univ. Press, New York.

Wittwer, S.H. 1965. Carbon dioxide levels in the biosphere: effects on plant productivity. Crit. Rev. Plan! Sci. 2:171-198.

Wittwer, S.H. 1966. Worldwidc status and hisrory of $\mathrm{CO}_{2}$ cnrichment-an overview. Carbon dioxide enrichment of greenhouse crops. vol. I. Status and $\mathrm{CO}_{2}$ sources. CRC Press, Boca Raton, Fla.

Wittwer, S.H. 1966. The greenhouse effect. Carolina Biol. Supply Co. Burlington. N.C.

Wittwer, S.H. and W. Robb. 1964. Carbon dioxide enrichment of greenhouse atmospheres for food crop production. Econ. Bor. 18:34-56.

WMO. 1963. Report of the WMO (CAS) meetig of the experts on the $\mathrm{CO}_{2}$ concentrations from pre-industrial times to I.G.Y., WCP-53. World Meteorological Organization Geneva. 